\title{
The influence of fat score and fat trimming on primal cut composition of South African lamb
}

\author{
P.E. Strydom ${ }^{1 \#}$, S.M. van Heerden ${ }^{1 \#}$, H.C. Schönfeldt ${ }^{2}$, R. Kruger ${ }^{2}$ and M.F. Smith ${ }^{3}$ \\ ${ }^{1}$ ARC-LBD: Animal Production Institute, Private Bag X2, Irene 0062, South Africa \\ ${ }^{2}$ Department of Business Economics, University of Pretoria, Pretoria 0002, South Africa \\ ${ }^{3}$ ARC - Biometry Unit, Private Bag X519, Silverton 0127, South Africa
}

\begin{abstract}
The objectives of this study were to evaluate the primal cut composition of South African lamb carcasses with different fat scores, and to identify cuts suitable for fat trimming. Sixty grain fed Dorper lambs (rams and ewes) were divided into three groups and slaughtered at 30, 36 and $42 \mathrm{~kg}$. Chilled carcass sides were subdivided into seven primal cuts. The cuts were dissected into meat (muscle, intermuscular and intramuscular fat), bone and subcutaneous fat (SCF) in order to determine the physical composition per cut and for the whole carcass. The \% subcutaneous fat (SCF) in the loin increased the most (26 units) as the fat score increased from 1 to 5 , followed by the flank, shoulder and neck. The $\%$ meat (lean) of the neck, thick rib and breast showed no significant change between fat scores 1 to 5 , while $\%$ bone decreased significantly (>6\% units). Meat and bone proportions decreased significantly with an increase in fat score for the loin, flank, leg and shoulder. The composition of the loin cut was most affected overall by changes in the fat score. Since different cuts accumulate SCF at different rates during fattening, trimming of SCF could reduce the boneless \% SCF level of the major cuts such as the loin, leg and shoulder by 12, 6 and 9 units, respectively, when trimmed from SCF equal to a fat score 5 to a fat score 3. Further trimming to levels equal to a fat score 1, could reduce the \% SCF by 18, 8 and 5 units, respectively on a boneless level. Considering differences in relative increase in intermuscular fat (IMF) and SCF in different cuts, the leg seems to be the most suitable cut for trimming in fat carcasses, since the IMF : SCF ratio is the lowest compared to the other larger cuts namely the loin and shoulder.
\end{abstract}

Keywords: Carcass composition, lamb, fat score, yield, trim

\# Corresponding authors. E-mail: pstrydom@arc.agric.za, ina@arc.agric.za

\section{Introduction}

In most parts of the world, leanness is an important criterion when consumers purchase meat (Carpenter, 1966; Sañudo et al., 2000). While a small amount of fat is desirable to sustain palatability, increase tenderness and decrease the risk of the meat drying out, too much fat is perceived as being unhealthy. According to Hopkins (1988), consumer perception of over-fatness leads to a downward trend in sheep meat consumption in Australia, while Hopkins \& Congram (1985) reported that Australian consumers did not want cuts of lamb with excessive fat. Sañudo et al. (2000) reported that too much fat discourages the consumer and is often removed either before cooking or during the meal, especially by young people. These reports agree with the South African National Meat Consumption Survey (2001) where consumers rated sheep meat (lamb and mutton) fourth in preference after poultry, fish and beef for four characteristics directly or indirectly relating their choice to fatness.

The lack of flexibility in the traditional way of presenting mutton carcasses in Australia and the USA to retailers and ultimately to the consumer was regarded by Garrett et al. (1992) as a major hurdle which contributed further to lower consumption. To overcome this problem, innovative methods where boneless fat-trimmed (even seam fat - intermuscular) sub-primals are presented to retailers were suggested by Garrett et al. (1992) to enable them to supply healthier, leaner retail cuts to the consumers. In the work of Hopkins et al. (1995) the introduction of "trim lamb" range of cuts where boneless, fat trimmed cuts and even muscle separation within primal cuts under the Prime Lamb Program in Australia is discussed. These cuts comply with Australian national heart foundation guidelines with a fat content $<10 \%$. With regard to the South African market, Van Heerden et al. (2007) showed that even though South African lamb and mutton are mainly produced and sold relatively lean, certain cuts even in leaner fat classes have too much fat according 
to nutritional guidelines, which may be one of the reasons why consumers regard sheep meat as probably too fat (South African National Meat Consumption Survey, 2001).

In South Africa, certain meat companies [Just Lamb (www.justlamb.co.za) and natLAM (www.lawmeat.co.za)] have altered at least a part of their operations to boneless retail cuts, although fatness is still mostly controlled by restriction of carcass fatness during production. Adjusting these operations to trim excess fat will not only result in a more acceptable product, but will also enable processors to use carcasses of various fat classes, thereby increasing the supply. However, as trimming is costly and could potentially add to the present high cost of sheep meat, it is necessary to have an estimate of the fat yield of different cuts to make this an economical proposition (Hopkins, 1988). Although Garrett et al. (1992) emphasized that seaming of the muscles i.e. separating the muscles, and removing all excess fat, was necessary to obtain an acceptable final fat level in the cuts, they worked with USDA yield grades 2, 3 and 4, representing fat thickness levels far in excess $(9 \mathrm{~mm}, 14$ and $20 \mathrm{~mm}$, respectively) of South African lamb (1 to $11 \mathrm{~mm}$ ) (Agricultural Product Standards ACT No. 119 of 1990).

In South Africa carcasses are classified into seven fat classes (Agricultural Product Standards ACT No. 119 of 1990) according to the visual appraisal of subcutaneous fat (SCF) cover. Carcasses classed as fat score 1 have less than 1\% SCF ( 0 mm back fat), while fat class 6 carcasses have in excess of 17.6\% SCF $(>11 \mathrm{~mm})$ back fat thickness. While the classification system describes the proportion of SCF of the total carcass in each fat class, no data exist for the composition of individual cuts and therefore the suitability of these cuts for trimming. In this study the composition of seven retail cuts with regard to SCF, meat (muscle, intermuscular fat and intra muscular fat) and bone of lamb carcasses of five different fat classes are compared. In addition the suitability of different cuts for trimming of excess SCF is investigated to present a more acceptable product to the consumer. It is accepted that normal trimming does not necessarily involve total removal of SCF and could also include removal of seam fat, although the latter process will need separation of individual muscles which is not common practice in South Africa for sheep meat due to the relatively small carcasses (and therefore muscles within cuts) produced.

\section{Materials and Methods}

Sixty Dorper lambs (rams and ewes, equally distributed over the slaughter groups) with a starting weight of between $23-26 \mathrm{~kg}$ were divided into three groups with equal mean weights. The three groups of animals were randomly allocated to three slaughter groups, viz. 30, 36 and $42 \mathrm{~kg}$. All animals were grain fed in individual pens $(1.5 \times 1 \mathrm{~m})$ and slaughtered when the target weight of each animal was reached within its slaughter group. Commercial slaughter and dressing procedures were followed.

On the day following slaughter, the chilled carcasses were sectioned down the vertebral column by band saw and one side subdivided into the following seven wholesale cuts: neck, shoulder and shank, breast, rib, loin, leg (Figure 1). The kidneys and kidney fat were removed and weighed for each carcass. The cut weights were recorded whereupon each cut was deboned and SCF removed. Weights of meat (including muscle, intermuscular and intramuscular fat), bone (including large sinews and cartilage) and SCF were recorded to calculate the physical composition of each cut and of the carcass side (and therefore the whole carcass). In addition, the physical composition of each boneless cut in terms of SCF and meat was also calculated.

Percentage SCF calculated for each carcass was used to allocate carcasses into five fat classes according to the fat classification criteria set out in the Agricultural Product Standards no 119 (1990; Table 1).

Since no muscle separation was done in the present trial, no data were recorded for intermuscular fat (IMF) of the carcass or individual cuts. For the purpose of benchmark values, deboning data including SCF and IMF proportions of different cuts of the lamb carcass with a fat score of 2 were obtained from the study of Van Heerden et al. (2007).

Data were analysed using the statistical programme, GenStat ${ }^{\circledR}$ (Payne et al., 2007). Factorial ANOVA was applied to test for differences in SCF, meat and bone proportions between five fat scores for each of seven cuts as well as the whole carcass. The data was normally distributed with homogeneous variances. Means were separated using Fisher's protected t-test LSD at the 5\% level. 


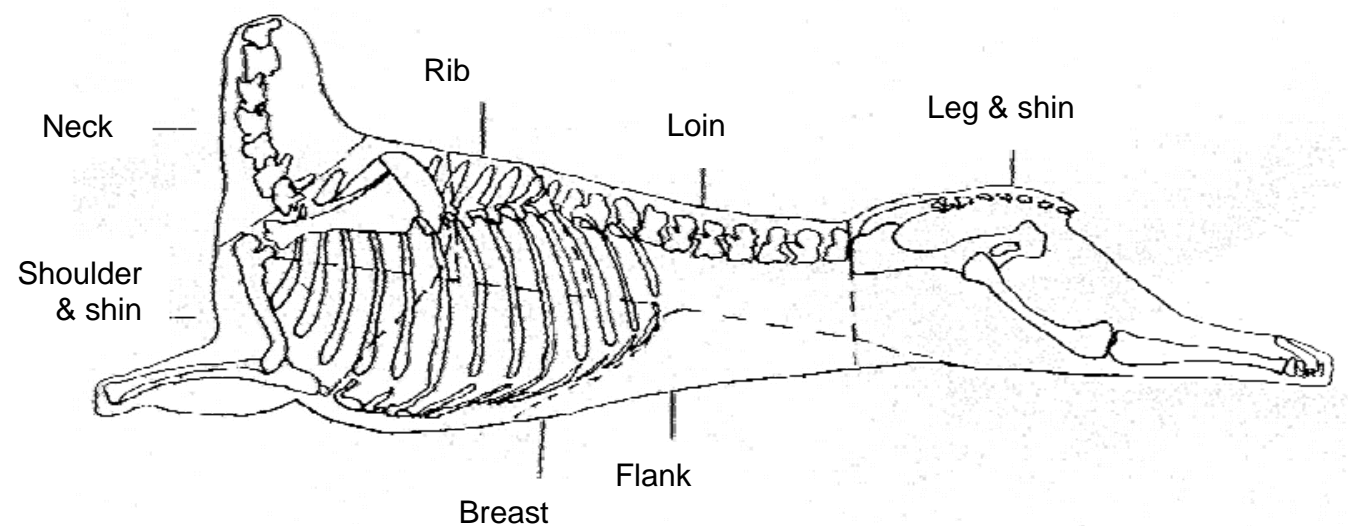

Figure 1 Dissection diagram describing the cutting guidelines for seven wholesale lamb carcass cuts (Casey, 1982).

Table 1 Allocation and description of carcasses in five fat score groups (Agricultural Product Standards No 119; 1990)

\begin{tabular}{|c|c|c|c|c|c|}
\hline Fat score & 1 & 2 & 3 & 4 & 5 \\
\hline $\begin{array}{l}\text { SCF guidelines } \\
\text { according to the } \\
\text { national classification } \\
\text { standards }(\%)^{1}\end{array}$ & $1.0-5.6$ & $5.6-8.6$ & $8.6-11.6$ & $11.6-14.6$ & $14.6-17.6$ \\
\hline $\begin{array}{l}\text { Number of carcasses } \\
\text { per fat class }\end{array}$ & 15 & 15 & 19 & 9 & 8 \\
\hline Mean SCF ${ }^{2}$ & $3.1(0.94)$ & $7.5(0.83)$ & $10.3(0.96)$ & $13.2(0.92)$ & $16.0(0.87)$ \\
\hline Carcass weights & $11.4(2.19)$ & $16.2(2.35)$ & $19.09(2.88)$ & $20.6(2.62)$ & $21.9(1.50)$ \\
\hline
\end{tabular}

Polynomial regression (orders 1 and 2) was applied to SCF over fat score to determine the best model of fit and estimate rate of change of SCF within each carcass cut.

\section{Results and Discussion}

Mean values showing the effect of fat score on SCF, meat and bone proportions of the carcasses and seven cuts are presented in Tables 2, 4 and 5, respectively. As expected, meat and bone proportions in the carcasses declined significantly $(\mathrm{P}<0.01)$ as the proportion of subcutaneous fat increased between fat scores 1 and 5. It is well known that muscle to bone ratio increases during initial growth (increase in weight). During the fattening period, fatty tissue grows at a greater rate than bone and muscle so that the proportions of both tissues decrease in a regular manner as fat increases (Fourie et al., 1970; Berg \& Butterfield, 1978; Thompson et al., 1979). Proportional changes of different tissue within cuts (or regions) are not as clearly documented because commercially defined carcass cuts are not the same worldwide and do not necessarily agree with anatomical grouping of tissues, such as muscle groups. Nevertheless, Hammond et al. (1971) and Berg \& Butterfield (1978) described the "growth curve" as starting at the head and spreading down to the trunk, while at the same time growth waves also start at the extremities of the limbs and pass upwards, all meeting at the junction of the loin and last rib, being the latest region to develop. 
Table 2 The effect of carcass fat score on the proportion of subcutaneous fat (SCF) in the carcasses and seven lamb cuts

\begin{tabular}{|c|c|c|c|c|c|c|}
\hline \multirow{2}{*}{ Cut } & \multirow{2}{*}{ Unit } & \multicolumn{5}{|c|}{ Carcass Fat Score } \\
\hline & & 1 & 2 & 3 & 4 & 5 \\
\hline Neck & $\%$ & $\begin{array}{c}3.5^{\mathrm{a}} \\
(0.610)\end{array}$ & $\begin{array}{c}7.7^{\mathrm{b}} \\
(0.589)\end{array}$ & $\begin{array}{c}8.3^{\mathrm{b}} \\
(0.524)\end{array}$ & $\begin{array}{l}10.9^{\mathrm{bc}} \\
(0.761)\end{array}$ & $\begin{array}{c}12.9^{\mathrm{c}} \\
(0.807)\end{array}$ \\
\hline $\begin{array}{l}\text { Shoulder and } \\
\text { shin }\end{array}$ & $\%$ & $\begin{array}{c}2.0^{\mathrm{a}} \\
(0.531)\end{array}$ & $\begin{array}{c}3.7^{\mathrm{a}} \\
(0.513)\end{array}$ & $\begin{array}{c}6.0^{\mathrm{b}} \\
(0.455)\end{array}$ & $\begin{array}{c}9.5^{c} \\
(0.662)\end{array}$ & $\begin{array}{c}13.3^{\mathrm{d}} \\
(0.702)\end{array}$ \\
\hline Rib & $\%$ & $\begin{array}{c}1.8^{\mathrm{a}} \\
(0.326)\end{array}$ & $\begin{array}{c}4.5^{\mathrm{b}} \\
(0.315)\end{array}$ & $\begin{array}{c}5.8^{\mathrm{bc}} \\
(0.279)\end{array}$ & $\begin{array}{c}7.0^{\mathrm{c}} \\
(0.406)\end{array}$ & $\begin{array}{l}9.3^{\mathrm{d}} \\
(0.431)\end{array}$ \\
\hline Breast & $\%$ & $\begin{array}{c}5.0^{\mathrm{a}} \\
(0.523)\end{array}$ & $\begin{array}{c}7.1^{\mathrm{ab}} \\
(0.505)\end{array}$ & $\begin{array}{c}9.1^{\mathrm{bc}} \\
(0.449)\end{array}$ & $\begin{array}{c}11.6^{\mathrm{cd}} \\
(0.652)\end{array}$ & $\begin{array}{c}12.2^{\mathrm{d}} \\
(0.692)\end{array}$ \\
\hline Leg and shin & $\%$ & $\begin{array}{c}2.9^{\mathrm{a}} \\
(0.419)\end{array}$ & $\begin{array}{c}7.0^{\mathrm{b}} \\
(0.404)\end{array}$ & $\begin{array}{c}9.9^{c} \\
(0.359)\end{array}$ & $\begin{array}{l}13.0^{\mathrm{d}} \\
(0.522)\end{array}$ & $\begin{array}{c}14.9^{\mathrm{d}} \\
(0.554)\end{array}$ \\
\hline Flank & $\%$ & $\begin{array}{l}6.5^{\mathrm{a}} \\
(0.943)\end{array}$ & $\begin{array}{c}13.5^{\mathrm{b}} \\
(0.911)\end{array}$ & $\begin{array}{l}18.2^{\mathrm{C}} \\
(0.809)\end{array}$ & $\begin{array}{c}19.7^{\mathrm{c}} \\
(1.176)\end{array}$ & $\begin{array}{c}19.5^{c} \\
(1.247)\end{array}$ \\
\hline Loin & $\%$ & $\begin{array}{c}1.8^{\mathrm{a}} \\
(0.907)\end{array}$ & $\begin{array}{c}12.6^{\mathrm{b}} \\
(0.876)\end{array}$ & $\begin{array}{c}17.9^{\mathrm{c}} \\
(0.779)\end{array}$ & $\begin{array}{c}21.7^{\mathrm{c}} \\
(1.131)\end{array}$ & $\begin{array}{c}29.0^{\mathrm{d}} \\
(1.200)\end{array}$ \\
\hline Carcass & $\%$ & $\begin{array}{c}3.0^{\mathrm{a}} \\
(0.243)\end{array}$ & $\begin{array}{c}7.5^{\mathrm{b}} \\
(0.235)\end{array}$ & $\begin{array}{l}10.3^{\mathrm{c}} \\
(0.209)\end{array}$ & $\begin{array}{c}13.2^{\mathrm{d}} \\
(0.303)\end{array}$ & $\begin{array}{c}16.0^{\mathrm{e}} \\
(0.321)\end{array}$ \\
\hline
\end{tabular}

a,b,c,d,e $\quad$ Row means with different superscripts differ $(\mathrm{P}<0.01)$.

Values in parentheses are standard errors of predicted means.

Fat deposition takes place in a similar pattern to that of muscle according to the earlier report of Hammond (1932) and supported by later reports of Berg \& Butterfield (1978), Thompson et al. (1979) and Butler-Hogg (1984), i.e. growth gradients from the distal limbs converging in the abdominal/lumbar region, which was clearly indicated in the present study too. SCF proportions of the seven retail cuts increased over increasing fat scores and in general changed at similar rates as the SCF of the whole carcass (Tables 2 and 3) with the exception of the loin and flank cuts. When regression lines were fitted to the SCF data, the neck, rib and breast showed best predictions with linear equations, while for the shoulder, leg, flank and loin the relationship with fat score was both linear and quadratic relationships. However, almost similar $\mathrm{R}^{2}$ and standard errors were found for linear equations of the latter cuts except for the flank that followed a strong quadratic nature (Figure 2). Proportional changes of the loin were much faster than those of the other cuts over all fat scores (larger linear incline), while that of the flank followed a strong increase in SCF between fat scores 1 to 3 and then tapered off towards fat score 5 . The shoulder and shin followed a slight exponential increase opposed to the other cuts (apart from the loin and flank) and carcass that increased strictly linearly or with a slight tapering slope (Table 3, Figure 2).

According to Tables 4 and 5, the increase in SCF proportions was associated with a decrease in the proportions of bone and meat or only decreased bone proportions within different cuts. For all seven cuts the proportional decline in bone between fat scores 1 and 5 was significant $(\mathrm{P}<0.01)$ and very similar varying between 6 and 9 percentage points (Table 5). Since bone is an early maturing carcass tissue (compared to muscle and fat), steady changes in bone proportions were expected since these were the result of muscle and fat changes during the initial predominantly muscle growth followed by higher rates of fat deposition during finishing of the carcass. Meat proportions of the breast rib and neck did not change significantly (Table 4), while that of the flank was a mirror image of changes in SCF (Table 2), by declining between fat scores 1 to 3 with no significant variation between fat scores 3 and 5 . As a result of the high increase in SCF proportions over all fat scores, \% meat in the loin declined significantly $(\mathrm{P}<0.05)$ between fat score 1 and 5 
with 18 units. Smaller but significant changes $(\mathrm{P}<0.05)$ also occurred in the shoulder and shin and leg and shin cuts.

Table 3 Prediction equations to demonstrate the change in the proportions of $\mathrm{SCF}^{1}(\%)$ (y) in seven lamb cuts over five fat scores (x) compared to carcass SCF

\begin{tabular}{|c|c|c|c|c|c|}
\hline Cut/Carcass & Model type & F-probability & Model & $\mathrm{R}^{2}(\%)$ & ${ }^{2}$ s.e. (\%) \\
\hline \multirow[t]{2}{*}{ Carcass } & Linear & $<0.001$ & $y=2.6194 x+0.204$ & 87.7 & 0.794 \\
\hline & Quadratic & 0.670 & $y=-0.034 x^{2}+2.448 x+0.496$ & 87.6 & 0.797 \\
\hline \multirow[t]{2}{*}{ Neck } & Linear & $<0.001$ & $y=2.173 x+2.176$ & 58.9 & 2.35 \\
\hline & Quadratic & 0.209 & $y=-0.140 x^{2}+2.98 x+1.26$ & 58.7 & 2.35 \\
\hline \multirow{2}{*}{ Shoulder and shin } & Linear & $<0.001$ & $y=2.694 x-1.313$ & 74.1 & 2.07 \\
\hline & Quadratic & 0.005 & $y=0.425 x^{2}+0.856 x+1.48$ & 76.8 & 1.96 \\
\hline \multirow[t]{2}{*}{ Thick rib } & Linear & $<0.001$ & $y=1.755 x+0.439$ & 77.0 & 1.24 \\
\hline & Quadratic & 0.333 & $y=-0.090 x^{2}+2.272 x-0.154$ & 77.0 & 1.24 \\
\hline \multirow[t]{2}{*}{ Breast } & Linear & $<0.001$ & $y=1.951 x+3.151$ & 63.2 & 1.93 \\
\hline & Quadratic & 0.343 & $y=-0.137 x^{2}+2.740 x+2.25$ & 63.1 & 1.93 \\
\hline \multirow{2}{*}{ Leg and shin } & Linear & $<0.001$ & $y=2.942 x+0.701$ & 87.9 & 1.42 \\
\hline & Quadratic & 0.029 & $y=-0.228 x^{2}+4.254 x-0.80$ & 88.7 & 1.37 \\
\hline \multirow[t]{2}{*}{ Flank } & Linear & $<0.001$ & $y=3.558 x+5.22$ & 56.3 & 4.05 \\
\hline & Quadratic & $<0.001$ & $y=-1.287 x^{2}+10.96 x-3.25$ & 68.4 & 3.45 \\
\hline \multirow[t]{2}{*}{ Loin } & Linear & $<0.001$ & $y=6.397 x-2.28$ & 83.3 & 3.72 \\
\hline & Quadratic & 0.015 & $y=-0.666 x^{2}+10.23 x-6.67$ & 84.6 & 3.57 \\
\hline
\end{tabular}

${ }^{1}$ SCF - Subcutaneous fat.

${ }^{2}$ s.e. - Standard error of observations.

While some work has been reported on the proportional development of muscles in cattle (Berg \& Butterfield (1978) and sheep (Lohse et al., 1971; Palsson \& Verges, 1952; Thonney et al., 1987), it is difficult to relate these results with the yield of commercial cuts, since anatomical muscle grouping often extends over cuts or various groups are contained within a commercial cut. Moreover, meat and not muscle yield was reported in the present study and therefore IMF was included in the proportions reported. The lack of change in meat proportions for cuts like the thick rib and breast cuts was therefore due to relatively high muscle or IMF accumulation or both, so that only bone proportions declined as a result of increased SCF. Such effects were reported by Diaz et al. (2005) for lean yield of the leg. Nevertheless, as stated earlier, the practice of separating muscle, therefore distinguishing between muscle and IMF is not common in sheep carcass processing, particularly in countries like South Africa where relatively small lamb carcasses are produced. Hopkins (1988) stated that seaming of muscles required heavy carcasses (22 - $25 \mathrm{~kg})$ to make it an economical and aesthetic proposition. The removal of only SCF to present a cut that is more acceptable to consumers and conform to nutritional standards will therefore depend on the amount of fat left after trimming the SCF. 


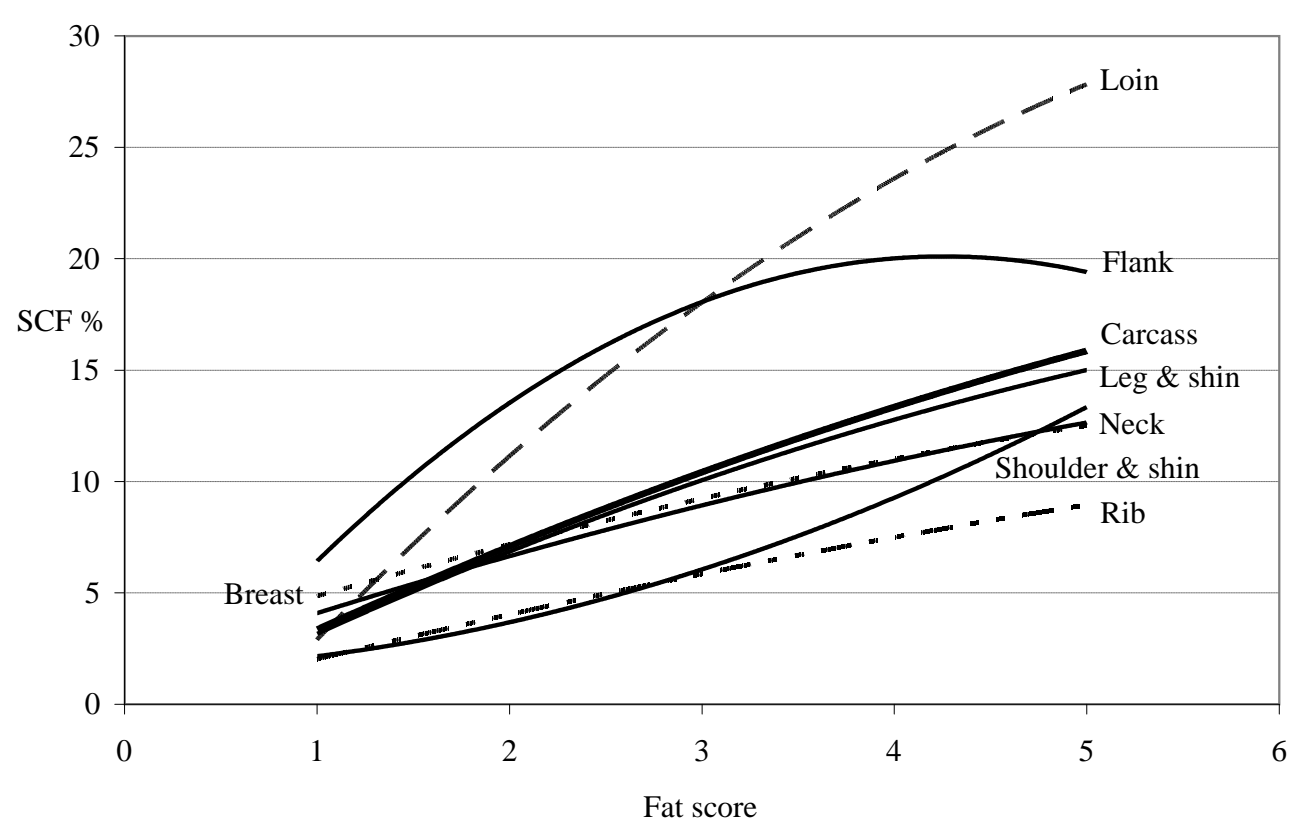

Figure 2 Regression lines describing the relationship between fat score and subcutaneous fat (SCF) proportions for seven lamb cuts.

Table 4 The effect of fat score on the proportions of meat in carcasses and seven lamb cuts

\begin{tabular}{|c|c|c|c|c|c|c|}
\hline \multirow{2}{*}{ Cut } & \multirow{2}{*}{ Unit } & \multicolumn{5}{|c|}{ Fat Score } \\
\hline & & 1 & 2 & 3 & 4 & 5 \\
\hline Neck & $\%$ & $\begin{array}{c}78.4 \\
(0.866)\end{array}$ & $\begin{array}{c}78.0 \\
(0.837)\end{array}$ & $\begin{array}{c}79.1 \\
(0.743)\end{array}$ & $\begin{array}{c}76.7 \\
(1.080)\end{array}$ & $\begin{array}{c}76.5 \\
(1.146)\end{array}$ \\
\hline $\begin{array}{l}\text { Shoulder } \\
\text { and shin }\end{array}$ & $\%$ & $\begin{array}{c}73.6^{\mathrm{ab}} \\
(0.543)\end{array}$ & $\begin{array}{c}75.4^{\mathrm{a}} \\
(0.524)\end{array}$ & $\begin{array}{c}73.7^{\mathrm{ab}} \\
(0.466)\end{array}$ & $\begin{array}{l}71.1^{\mathrm{bc}} \\
(0.677)\end{array}$ & $\begin{array}{c}68.2^{\mathrm{c}} \\
(0.718)\end{array}$ \\
\hline Thick rib & $\%$ & $\begin{array}{c}74.4 \\
(0.683)\end{array}$ & $\begin{array}{c}76.3 \\
(0.660)\end{array}$ & $\begin{array}{c}76.5 \\
(0.586)\end{array}$ & $\begin{array}{c}76.2 \\
(0.852)\end{array}$ & $\begin{array}{c}75.6 \\
(0.904)\end{array}$ \\
\hline Breast & $\%$ & $\begin{array}{c}73.7 \\
(0.607)\end{array}$ & $\begin{array}{c}75.0 \\
(0.586)\end{array}$ & $\begin{array}{c}73.8 \\
(0.521)\end{array}$ & $\begin{array}{c}73.0 \\
(0.757)\end{array}$ & $\begin{array}{c}74.2 \\
(0.803)\end{array}$ \\
\hline $\begin{array}{l}\text { Leg and } \\
\text { shin }\end{array}$ & $\%$ & $\begin{array}{c}77.7^{\mathrm{a}} \\
(0.524\end{array}$ & $\begin{array}{l}76.5^{\mathrm{ab}} \\
(0.506\end{array}$ & $\begin{array}{l}74.7^{\mathrm{bc}} \\
(0.450\end{array}$ & $\begin{array}{l}72.6^{\text {cd }} \\
(0.654\end{array}$ & $\begin{array}{c}71.3^{\mathrm{d}} \\
(0.693\end{array}$ \\
\hline Flank & $\%$ & $\begin{array}{c}90.9^{\mathrm{a}} \\
(0.963)\end{array}$ & $\begin{array}{c}84.8^{\mathrm{b}} \\
(0.930)\end{array}$ & $\begin{array}{c}80.2^{\mathrm{C}} \\
(0.826)\end{array}$ & $\begin{array}{c}78.9^{\mathrm{c}} \\
(1.201)\end{array}$ & $\begin{array}{c}79.2^{\mathrm{c}} \\
(1.273)\end{array}$ \\
\hline Loin & $\%$ & $\begin{array}{c}78.0^{\mathrm{a}} \\
(0.915)\end{array}$ & $\begin{array}{c}74.2^{\mathrm{a}} \\
(0.884)\end{array}$ & $\begin{array}{c}68.1^{\mathrm{b}} \\
(0.786)\end{array}$ & $\begin{array}{c}67.6^{\mathrm{b}} \\
(1.141)\end{array}$ & $\begin{array}{c}59.8^{\mathrm{c}} \\
(1.211)\end{array}$ \\
\hline Carcass & $\%$ & $\begin{array}{c}77.1^{\mathrm{a}} \\
(0.339)\end{array}$ & $\begin{array}{c}76.6^{\mathrm{a}} \\
(0.327)\end{array}$ & $\begin{array}{c}74.6^{\mathrm{b}} \\
(0.291)\end{array}$ & $\begin{array}{c}73.0^{\mathrm{b}} \\
(0.422)\end{array}$ & $\begin{array}{c}71.1^{\mathrm{b}} \\
(0.448)\end{array}$ \\
\hline
\end{tabular}

a,b,c,d Row means with different superscripts differ $(\mathrm{P}<0.001)$.

Values in parentheses are standard errors of predicted means. 
(c) South African Society for Animal Science

Table 5 The effect of fat score on the proportion of bone in carcasses and seven lamb cuts

\begin{tabular}{|c|c|c|c|c|c|c|}
\hline \multirow{2}{*}{ Cut } & \multirow{2}{*}{ Unit } & \multicolumn{5}{|c|}{ Fat Score } \\
\hline & & 1 & 2 & 3 & 4 & 5 \\
\hline Neck & $\%$ & $\begin{array}{c}18.2^{\mathrm{a}} \\
(0.581)\end{array}$ & $\begin{array}{c}14.3^{\mathrm{b}} \\
(0.561)\end{array}$ & $\begin{array}{c}12.6^{\mathrm{b}} \\
(0.499)\end{array}$ & $\begin{array}{l}12.5^{\mathrm{bc}} \\
(0.725)\end{array}$ & $\begin{array}{c}10.6^{\mathrm{c}} \\
(0.769)\end{array}$ \\
\hline $\begin{array}{l}\text { Shoulder } \\
\text { and shin }\end{array}$ & $\%$ & $\begin{array}{c}24.3^{\mathrm{a}} \\
(0.464)\end{array}$ & $\begin{array}{c}20.9^{\mathrm{b}} \\
(0.448)\end{array}$ & $\begin{array}{c}20.3^{b} \\
(0.398)\end{array}$ & $\begin{array}{c}19.4^{\mathrm{b}} \\
(0.578)\end{array}$ & $\begin{array}{c}18.6^{\mathrm{b}} \\
(0.613)\end{array}$ \\
\hline Thick rib & $\%$ & $\begin{array}{c}23.9^{\mathrm{a}} \\
(0.655)\end{array}$ & $\begin{array}{c}19.35^{\mathrm{b}} \\
(0.632)\end{array}$ & $\begin{array}{c}17.8^{\mathrm{bc}} \\
(0.562)\end{array}$ & $\begin{array}{c}16.8^{\mathrm{bc}} \\
(0.816)\end{array}$ & $\begin{array}{c}15.2^{\mathrm{c}} \\
(0.866)\end{array}$ \\
\hline Breast & $\%$ & $\begin{array}{c}21.4^{\mathrm{a}} \\
(0.502)\end{array}$ & $\begin{array}{c}17.9^{\mathrm{b}} \\
(0.485)\end{array}$ & $\begin{array}{c}17.1^{\mathrm{b}} \\
(0.431)\end{array}$ & $\begin{array}{c}15.4^{\mathrm{bc}} \\
(0.626)\end{array}$ & $\begin{array}{c}13.6^{\mathrm{c}} \\
(0.664)\end{array}$ \\
\hline $\begin{array}{l}\text { Leg and } \\
\text { shin }\end{array}$ & $\%$ & $\begin{array}{c}19.4^{\mathrm{a}} \\
(0.420)\end{array}$ & $\begin{array}{c}16.5^{\mathrm{b}} \\
(0.046)\end{array}$ & $\begin{array}{c}15.4^{\mathrm{bc}} \\
(0.361)\end{array}$ & $\begin{array}{c}14.4^{\mathrm{bc}} \\
(0.524)\end{array}$ & $\begin{array}{c}13.8^{\mathrm{c}} \\
(0.556)\end{array}$ \\
\hline Flank & $\%$ & $\begin{array}{c}2.6 \\
(0.294)\end{array}$ & $\begin{array}{c}1.7 \\
(0.284)\end{array}$ & $\begin{array}{c}1.6 \\
(0.253)\end{array}$ & $\begin{array}{c}1.4 \\
(0.367)\end{array}$ & $\begin{array}{c}1.3 \\
(0.389)\end{array}$ \\
\hline Loin & $\%$ & $\begin{array}{c}20.2^{\mathrm{a}} \\
(0.852)\end{array}$ & $\begin{array}{c}13.3^{\mathrm{b}} \\
(0.823)\end{array}$ & $\begin{array}{c}14.0^{\mathrm{b}} \\
(0.731)\end{array}$ & $\begin{array}{c}10.7^{\mathrm{b}} \\
(1.063)\end{array}$ & $\begin{array}{c}11.3^{\mathrm{b}} \\
(1.127)\end{array}$ \\
\hline Carcass & $\%$ & $\begin{array}{c}19.83 \\
(0.394)\end{array}$ & $\begin{array}{c}16.0^{\mathrm{C}} \\
(0.380)\end{array}$ & $\begin{array}{c}15.1^{\mathrm{bc}} \\
(0.338)\end{array}$ & $\begin{array}{c}13.8^{\mathrm{ab}} \\
(0.491)\end{array}$ & $\begin{array}{c}12.9^{\mathrm{a}} \\
(0.521)\end{array}$ \\
\hline
\end{tabular}

$\overline{a, b, c}$ Row means with different superscripts differ $(\mathrm{P}<0.001)$.

Values in parentheses are standard errors of predicted means.

Little information is available regarding the minimum fat covering needed on a lamb carcass in order to ensure the desired product. Carpenter (1966) stated that a fat covering of at least $5 \mathrm{~mm}$ is needed to prevent product dehydration and to produce an attractive retail cut. Five millimetres of SCF is equal to a fat score 3 in the South African classification system but preferences will of course vary from consumer group to consumer group. Furthermore, this value is a mean value mostly measured on the loin, and other cuts may have more or less fat cover and also differ in their appeal to consumers. Considering the major cuts of a lamb carcass most likely to be trimmed, trimming fat score 5 carcasses to a SCF level equal to fat score 3, will reduce the SCF level (\%) by 12 units for the loin, almost 6 units for the leg and 9 units for the shoulder in boneless cuts (Table 6). Further trimming to SCF levels equal to fat score 1 will reduce the \% SCF with a further 18, 8 and 5 units on a boneless level for these three cuts. Hopkins (1988) worked with bone in cuts that were trimmed of excess SCF, while IMF (seam fat) was left intact, and concluded that trimming of SCF alone could remove most of the differences in composition of lamb cuts from carcasses of different fatness. He did, however, admit that the amount of untrimmed fat (mostly seam fat), increased with increase in fat score. Considering the ratios of intermuscular fat to SCF of retail cuts of a fat score 2 carcass (Table 7; Van Heerden et al., 2007), the total fat of shoulder, leg and loin cuts will be $\sim 7,12$ and 29\%, respectively (calculated from Table 6). If these cuts were trimmed to SCF levels equal to fat score 1, the remaining fat will be $\sim 4,7$ and $13 \%$, respectively.

Since the objective of trimming is to target fatter carcasses (Hopkins, 1988), the relative increase in SCF and IMF with increasing fat score has to be considered. In this regard, Butler-Hogg (1984), Fourie et al. (1970), Jones (1982) and Kempster et al. (1987) reported allometric growth coefficients for IMF relative to SCF of 0.5 to 0.75 for the carcass in general, indicating that SCF is much later maturing than IMF. For individual cuts, Kempster et al. (1987) reported ratios of 0.47 for the leg (0.7 vs. 1.51), 0.65 for the shoulder (1.19 vs. 1.82) and between 0.70 and 0.76 for the loin (1.74 vs. 2.46), breast (1.63 vs. 2.26), rib (1.74 vs. 2.44) and neck cuts (1.39 vs. 1.82). (Allometric coefficients are relative to carcass weight). This clearly 
shows that IMF is early maturing and SCF late maturing for all cuts but the actual rate of growth varies among cuts.

Table 6 The effect of fat score on the proportions of subcutaneous fat in the boneless carcass and boneless lamb cuts

\begin{tabular}{|c|c|c|c|c|c|c|}
\hline \multirow{2}{*}{ Cut } & \multirow{2}{*}{ Unit } & \multicolumn{5}{|c|}{ Fat score } \\
\hline & & 1 & 2 & 3 & 4 & 5 \\
\hline Carcass & $\%$ & $\begin{array}{c}3.8^{\mathrm{a}} \\
(0.270)\end{array}$ & $\begin{array}{c}8.9^{\mathrm{b}} \\
(0.261)\end{array}$ & $\begin{array}{c}12.1^{\mathrm{C}} \\
(0.232)\end{array}$ & $\begin{array}{l}15.3^{\mathrm{d}} \\
(0.337)\end{array}$ & $\begin{array}{c}18.4^{\mathrm{e}} \\
(0.358)\end{array}$ \\
\hline Neck & $\%$ & $\begin{array}{c}4.3^{\mathrm{a}} \\
(0.707)\end{array}$ & $\begin{array}{c}9.0^{\mathrm{b}} \\
(0.683)\end{array}$ & $\begin{array}{c}9.5^{\mathrm{b}} \\
(0.607)\end{array}$ & $\begin{array}{c}12.5^{\mathrm{c}} \\
(0.881)\end{array}$ & $\begin{array}{c}14.4^{\mathrm{c}} \\
(0.935)\end{array}$ \\
\hline $\begin{array}{l}\text { Shoulder } \\
\text { and shin }\end{array}$ & $\%$ & $\begin{array}{c}2.7^{\mathrm{a}} \\
(0.652)\end{array}$ & $\begin{array}{c}4.6^{\mathrm{b}} \\
(0.630)\end{array}$ & $\begin{array}{c}7.5^{c} \\
(0.560)\end{array}$ & $\begin{array}{l}11.8^{\mathrm{d}} \\
(0.814)\end{array}$ & $\begin{array}{l}16.3^{\mathrm{e}} \\
(0.863)\end{array}$ \\
\hline Rib & $\%$ & $\begin{array}{c}2.3^{\mathrm{a}} \\
(0.394)\end{array}$ & $\begin{array}{c}5.6^{\mathrm{b}} \\
(0.380)\end{array}$ & $\begin{array}{c}7.0^{\mathrm{b}} \\
(0.338)\end{array}$ & $\begin{array}{c}8.4^{\mathrm{b}} \\
(0.491)\end{array}$ & $\begin{array}{c}10.9^{c} \\
(0.521)\end{array}$ \\
\hline Breast & $\%$ & $\begin{array}{c}6.3^{\mathrm{a}} \\
(0.615)\end{array}$ & $\begin{array}{c}8.6^{\mathrm{a}} \\
(0.594)\end{array}$ & $\begin{array}{c}10.9^{\mathrm{b}} \\
(0.528)\end{array}$ & $\begin{array}{c}13.8^{\mathrm{b}} \\
(0.767)\end{array}$ & $\begin{array}{c}14.2^{\mathrm{b}} \\
(0.813)\end{array}$ \\
\hline $\begin{array}{l}\text { Leg and } \\
\text { shin }\end{array}$ & $\%$ & $\begin{array}{c}3.6^{\mathrm{a}} \\
(0.482)\end{array}$ & $\begin{array}{c}8.4^{\mathrm{b}} \\
(0.466)\end{array}$ & $\begin{array}{c}11.7^{\mathrm{c}} \\
(0.414)\end{array}$ & $\begin{array}{c}15.2^{\mathrm{d}} \\
(0.601)\end{array}$ & $\begin{array}{l}17.3^{\mathrm{d}} \\
(0.638)\end{array}$ \\
\hline Flank & $\%$ & $\begin{array}{c}6.7^{\mathrm{a}} \\
(0.959)\end{array}$ & $\begin{array}{c}13.7^{\mathrm{b}} \\
(0.926)\end{array}$ & $\begin{array}{l}18.5^{c} \\
(0.823)\end{array}$ & $\begin{array}{l}20.0^{\mathrm{c}} \\
(1.20)\end{array}$ & $\begin{array}{c}19.8^{\mathrm{c}} \\
(1.168)\end{array}$ \\
\hline Loin & $\%$ & $\begin{array}{c}2.2^{\mathrm{a}} \\
(1.000)\end{array}$ & $\begin{array}{c}14.4^{\mathrm{b}} \\
(0.966)\end{array}$ & $\begin{array}{c}20.7^{\mathrm{c}} \\
(0.859)\end{array}$ & $\begin{array}{c}24.3^{\mathrm{c}} \\
(1.247)\end{array}$ & $\begin{array}{c}32.6^{\mathrm{d}} \\
(1.323)\end{array}$ \\
\hline
\end{tabular}

Values in parentheses are standard errors of predicted means.

Table 7 Relative proportions of subcutaneous fat (SCF )and intermuscular fat (IMF) in seven cuts of lamb carcasses with a fat score of 2 (from Van Heerden et al., 2007)

\begin{tabular}{ccccccccc}
\hline \multirow{2}{*}{$\begin{array}{c}\text { Fat } \\
\text { depot }\end{array}$} & & Neck & $\begin{array}{c}\text { Shoulder } \\
\text { and shin }\end{array}$ & Rib & Breast & $\begin{array}{c}\text { Leg and } \\
\text { shin }\end{array}$ & Flank & Loin \\
\hline SCF & $\%$ & 34 & 63 & & 48 & 69 & & 49 \\
IMF & $\%$ & 66 & 37 & $100^{1}$ & 52 & 31 & $100^{1}$ & 51 \\
\hline
\end{tabular}

${ }^{1}$ SCF and IMF were not separated in the flank and rib cuts.

Considering the ratios of IMF to SCF for fat score 2 in Table 7 and the results of Kempster et al. (1987) and Palsson \& Verges (1952) for the shoulder, loin and leg, the high increase in SCF in the loin towards higher fat scores in the present trial will be accompanied by a large increase in IMF as well. The shoulder will follow more or less the same trend and the IMF may increase to 50\% of the SCF (Palsson \& Verges, 1952). The only cut fit for trimming at high fat scores seems to be the leg as most of the fat is deposited in the SCF depot (Table 7) and the relative increase in SCF should be much higher than that of 
(C) South African Society for Animal Science

IMF according to Kempster et al. (1987). Palsson \& Verges (1952) also reported that IMF of the leg was $20 \%$ of the total fat at 41 weeks in lambs on a high feeding plane.

\section{Conclusions}

The change in carcass cut composition of South African lamb between fat scores 1 and 5 has been documented in this paper. It can be concluded that lambs slaughtered within these fat scores will gain SCF at very similar rates among most cuts and the carcass as a whole. The only exceptions are the flank and loin cuts, where the flank gains SCF exponentially with high gains in initial fattening stages which slow down when the carcass becomes fatter. SCF deposition in the loin takes place at a higher rate than the carcass and individual cuts between fat scores 1 and 5 .

Extrapolating from results of other studies, of the major cuts most likely to be trimmed, the leg cut is the most suitable, as most of the total fat accumulates in the SCF depot when carcasses become over fat. Nevertheless, when it is considered that carcasses of extreme fatness are not economically produced and probably not commonly available, fat trimming should preferably occur on medium or slightly over fat carcasses (fat scores 3 and 4), which will probably render cuts like the shoulder and loin more suitable for SCF trimming to produce an acceptable end product.

\section{Acknowledgements}

Thank you to the personnel of the Analytical Services as well as the abattoir team of the ARC-LBD: Animal Production - ARC-Irene, for their technical assistance that is greatly acknowledged.

\section{References}

Berg, R.T. \& Butterfield, R.M., 1978. New Concepts of Cattle Growth. $2^{\text {nd }}$ ed., Sydney University Press, Sydney, Australia.

Butler-Hogg, B.W., 1984. The growth of Clun and Southdown sheep: Body composition and partitioning of total body fat. Anim. Prod. 39, 405-411.

Carpenter, Z.L., 1966. What is consumer-preferred lamb? S. Afr. J. Anim. Sci. 25, 1232-1235.

Casey, N.H., 1982. Carcass and growth characteristics of four South African sheep breeds and the Boer goat. D.Sc. Agric thesis, University of Pretoria, South Africa.

Diaz, M.T., De la Fuente, J., Lauzurica, S., Pérez, C., Velasco, S., Álvarez, I., Ruiz de Huidobro, F., Onega, E., Blázquez, B. \& Cañeque, V., 2005. Use of carcass weight to classify Manchego sucking lambs and its relation to carcass and meat quality. Anim. Sci. 80, 61-69.

Fourie, P.D., Kirton, A.H. \& Jury, K.E., 1970. Growth and development of sheep II. Effect of breed and sex on the growth and carcass composition of Southdown and Romney and their cross. N. Z. J. Agric. Res. 13, 753-770.

Garrett, R.P., Savell, J.W., Cross, H.R. \& Johnson, H.K., 1992. Yield grade and carcass weight effects on the cutability of lamb carcasses fabricated into innovative style subprimals. J. Anim. Sci. 70, 1829-39.

Hammond, J., 1932. A survey of the problems involved in meat production: Growth and the development of mutton qualities in the sheep. Oliver and Boyd, Edinburgh, UK.

Hammond Jr, J., Mason, I.L. \& Robinson, T.J., 1971. Hammond's Farm Animals. $4^{\text {th }}$ ed., Edward Arnold, London, UK.

Hopkins, A.F. \& Congram, I.D., 1985. Consumer usage and attitudes towards lambs. Livestock and Meat Authority of Queensland, Brisbane, Research Report No. 18.

Hopkins, D.L., 1988. Composition of trimmed retail lamb cuts. Proc. $34^{\text {th }}$ Int. Cong. Meat Sci. Technol. pp. 78-79.

Hopkins, D.L., Watton, J.S.A., Gamble, D.J., Atkinson, W.R., Slack-Smith, T.S. \& Hall, D.G., 1995. Lamb carcass characteristics. 1 . The influence of carcass weight, fatness, and sex on the weight of "trim" and traditional retail cuts. Aust. J. Exp. Agric. 35, 33-40.

Jones, S.D.M., 1982. The accumulation and distribution of fat in ewe and ram lambs. Can. J. Anim. Sci. 62, 381-386.

Just Lamb, 2009. Unique by nature. [Online]. Available from: (http://wwww.justlamb.co.za. [Accessed: 12/02/2009]. 
Kempster, A.J., Croston, D. \& Jones, D.W., 1987. Tissue growth and development in crossbred lambs sired by ten breeds. Livest. Prod. Sci. 16, 145-162.

Lohse, C.L., Moss, F.P. \& Butterfield, R.M., 1971. Growth patterns of muscle of merino sheep from birth to 517 days. Anim. Prod. 13, 117-126.

Department of Agriculture, 1990. Regulations regarding the classification and marketing of meat. Agricultural Product Standards, ACT No 119 of 1990.

natLAM. 2009. Certified Natural. [Online]. Available from: www.lawmeat.co.za [Accessed: 12/02/2009].

Palsson, H. \& Vergés, J.B., 1952. Effects of plane of nutrition on growth and the development of carcass quality in lambs. I. The effects of high and low planes of nutrition at different ages. J. Agric. Sci. 42, 2-88.

Payne, R.W., Murray, D.A., Harding, S.A., Baird, D.B. \& Soutar, D.M., 2007. Genstat for Windows® (10th ed.). Introduction. VSN International, Hemel Hempstead, UK.

Sañudo, C., Enser, M.E., Campo, M.M., Nute, G.R., Maria, G., Sierra, I. \& Wood, J.D., 2000. Fatty acid composition and sensory characteristics of lamb carcasses from Britain and Spain. Meat Sci. 54, 339-345.

South African National Meat Consumption Survey, 2001. Conducted by A.C. Nielson, a global marketing research firm, on behalf of the South African Feedlot Association. (Unpublished).

Thompson, J.M., Atkins, K.D. \& Gilmour, A.R., 1979. Carcass characteristics of heavyweight crossbred lambs. II. Carcass composition and partitioning of fat. Aust. J. Agric. Res. 30, 1207-1214.

Thonney, M.L., Taylor, C.S., Murray, J.I. \& McClelland, T.H., 1987. Breed and sex differences in equally mature sheep and goats. 3. Muscle weight distribution. Anim. Prod. 45, 277-290.

Van Heerden, S.M., Schönfeldt, H.C., Kruger, R. \& Smith, M.F., 2007. The nutrient composition on South African lamb (A2 grade). J. Food Compos. Anal. 20, 671-680. 